\title{
KEANEKARAGAMAN DAN POTENSI JAMUR MAKRO DI KAWASAN SUAKA MARGASATWA BUKIT RIMBANG BUKIT BALING (SMBRBB) PROPINSI RIAU, SUMATERA
}

\author{
Noverita $^{1^{*}}$, Dennys Perdana Armanda ${ }^{2}$, Ikhsan Matondang ${ }^{3}$, Tatang Mitra Setia ${ }^{4}$, \\ dan Ratna Wati ${ }^{5}$ \\ ${ }^{1,2,3}$ Faculty of Biology, Universitas Nasional, Jakarta \\ ${ }^{4,5}$ Magister Program of Biology, Graduate School, Universitas Nasional, Jakarta \\ *Corresponding author: noverita.unas@yahoo.co.id
}

\begin{abstract}
The Bukit Rimbang Bukit Baling Wildlife Reserve Area (SMBRBB) Riau is one of the areas that has the characteristics of lowland rainforest types with high biodiversity, so it is possible to find many macro fungi, but there is no data on macrofungi diversity. This research was conducted with the aim of obtaining diversity data and potential data on macrofungi, both as food ingredients and as medicinal ingredients. This study uses a searching method that is modified by the path method using sample plots. 138 macrofungi species were obtained, which included 52 genera, 37 families and 3 phyla. Macrofungi diversity index at this location is relatively moderate, and high uniformity index. 66 species potentially as medicinal ingredients, including Amauroderma rugosum, Ganoderma aplanatum, Ganoderma lucidum, Lentinus sajo-caju, Lentinus squamolosus, Cymatoderma elegans, Daldinea concentrica, Microporus xantopus, M. afinitis, Pycnoporus cinnabarius, Polyporus arcularius, Rigidoporus microporus, Rigidoporus microporus, Trametes versikularis, and Xylaria longipes. As many as 32 species have potential as food ingredients, including Auricularia auricula, Auricularia delicata, Auricularia polytricha, Cookeina sulcipes, Phallus indusiatus, Lentinus sajor-caju, Lentinus squamolosus, Pleurotus ostreatus, Schizophyllum commune, Tramella fuciformis, and Volvariellavolvacea.
\end{abstract}

Keywords: cultivation, diversity, food, makrofungi, medicine.

\section{PENDAHULUAN}

Indonesia dikenal sebagai negara megadiversitas karena berbagai jenis flora dan fauna yang ditemukan jumlahnya hampir lebih dari separuh kenekaragaman flora dan fauna dunia, termasuk di dalamnya fungi khususnya makrofungi. Hilman dan Romadoni (2001) menyatakan bahwa dari 1,5 juta spesies yang telah diidentifikasi di muka bumi ini hampir setengahnya ada di Indonesia, dimana 25\% diantaranya terdiri dari fungi (jamur). Namun sampai saat ini data pasti mengenai biodiversitas jamur terutama jamur makro di Indonesia belum ada. Dilain pihak, kita dihadapkan dengan cepatnya laju penurunan keanekaragaman hayati baik oleh proses alamiah maupun oleh ulah manusia, seperti terjadinya kerusakan hutan. Oleh karena itu, selayaknya kita melakukan penelitian terkait keanekaragaman jamur makro yang ada di kawasan-kawasan dan hutan-hutan yang ada di Indonesia, agar dapat mengungkap kekayaan alam Indonesia secara pasti. Selain itu, untuk melihat potensi dari keanekaragaman tersebut dan untuk menjaga kelestariannya, perlu adanya usaha budi daya terhadap jamur makro tersebut, agar pengekplorasian secara terus menerus ke alam dapat dihindari.

Penelitian tentang keanekaragaman jamur makro, khususnya di Sumatera sudah banyak di 
lakukan, diantaranya hasil penelitian. Tambubolon et al. (2012) di Hutan Pendidikan Universitas Sumatera Utara, Desa Tongkoh Kabupaten Karo, menemukan 46 jenis jamur makro, yang terdiri atas 2 divisi, 4 kelas, 10 bangsa, dan 21 suku, dimana jumlah jenis jamur bervasi pada setiap perbedaan ketinggian. Tyaningsih et al. (2014) di kawasan penyangga perkebunan kelapa sawit Kiliran Jao, Kabupaten Sijunjung Sumatera Barat, menemukan sebanyak 25 jenis jamur makro yang termasuk kedalam 3 kelas, 5 bangsa, 8 suku, dan 14 marga. Suku tebanyak yang ditemukan adalah Polyporaceae dengan 11 jenis. Sari et al. (2016) di Kawasan Air Terjun Curuk Pandan Kabupaten Lahat, menemukan 20 jenis jamur makro dari filum Basidiomycota yang termasuk ke dalam 5 bangsa dan 10 suku. Jenis yang paling banyak ditemukan adalah dari bangsa Agaricales yaitu Coprinus disseminatus, Mycena chlorophos, Mycena rosella, Favolaschia calocera, Marasmius androsaceus, Micromphale foetidum, Cyptotrama asprata, Psathryrella, dan Schizophyllum commune, diikuti bangsa Polyporales yaitu Cymatoderma elegans, Lenzites elegans, Lentinus sajor-caju, Earliella scabrosa, Trametes elegans, Pycnoporus sanguineus. Lenzites sp, dan Microporus xanthopus. Fatayaturrahmi et al.

Penelitian Ermanita et al. (2017) di Korong Tanjung Kasang Kecamatan Batang Anai, Kabupaten Padang Pariaman, ditemukan sebanyak 21 jenis jamur makro dari Filum
Basidiomycota, yang termasuk ke dalam 2 kelas, 4 bangsa, 9 suku, dan 17 marga. Selanjutan Noverita et al. (2017) di Cagar Alam Lembah Anai dan Cagar Alam Batang Palupuh, menemukan sebanyak 112 jenis jamur makro, yang terdiri dari 63 jenis di kawasan Cagar Alam Lembah Anai, dan 58 jenis di Cagar Alam Batang Palupuah.

Kawasan Suaka Margasatwa Bukit Rimbang Bukit Baling (SMBRBB) Riau, merupakan salah satu kawasan yang menjadi pilihan dalam penelitian ini, karena kawasan ini unik, memiliki karakteristik tipe hutan hujan basah dataran rendah dengan keanekaragaman hayati tinggi dan menjadi habitat berbagai jenis satwa langka yang terancam punah. Kondisi ini sangat memungkinkan banyak ditemukan jamur makro, namun di kawasan ini belum ada data keanekaragaman jamur makro, baik data secara umum maupun data yang punya nilai ekonomi (potensi pangan dan obat).

Penelitian ini bertujuan untuk mendapatkan data keanekaragaman jamur makro di kawasan tersebut, termasuk data yang punya nilai ekonomi baik sebagai bahan pangan maupun sebagai bahan obat. Manfaat dari peenelitian ini diketahui jumlah kenekaragaman jamur makro di Kawasan Suaka Margasatwa Bukit Rimbang Bukit Baling (SMBRBB) Riau, dan diketahui jenisjenis jamur makro yang berpotensi baik sebagai bahan pangan maupun sebagai bahan obat, yang nantinya dapat diupayakan untuk 
Noverita, dkk: Keanekaragaman dan Potensi Jamur Makro di Kawasan Suaka Margasatwa Bukit Rimbang Bukit Baling (SMBRBB) Propinsi Riau, Sumatera

dibudidayakan sebagai alternatif dalam peningkatan taraf hidup masyarakat.

\section{METODE PENELITIAN}

\section{Tempat dan Waktu Penelitian}

Penelitian ini merupakan penelitian lapangan dan laboratorium. Inventarisasi dilakukan di Kawasan Suaka Margasatwa Bukit Rimbang Bukit Baling (SMBRBB) Riau, Identifikasi lanjut serta pembuatan bibit F0 dilakukan di Laboratorium Mikrobiologi dan Genetika, serta Rumah Jamur Laboratorium Terpadu Universitas Nasional Jakarta. Waktu penelitian direncanakan dimulai dari bulan Maret 2016 sampai dengan Agustus 2016.

\section{Alat dan Bahan Penelitian}

Alat yang digunakan selama penelitian adalah; peta lokasi penelitian, tabulasi data, alat tulis, papan jalan, kertas koran, label, botol sampel, tabung biakan, $\mathrm{pH}$ meter, hygrometer,altimeter, thermometer, box ,kamera digital, mikroskop, objek dan cover glass, bunsens, buku-buku identifikasi jamur, autoclav, oven, inkubator, laminar air flow, tabung reaksi, cawan Petri, erlenmeyer, timbangan, jarum inokulasi, kompor gas, drum sterilisasi, bag log dan botol bibit.

Bahan yang digunakan dalam penelitian ini adalah; karton hitam dan putih, kantong plastik, Alkohol 70\%, formalin 4\%, kapas, akuades, medium PDA, dan laktofenol, Media PDA, spirtus, alkohol 70\%, plastik tahan panas, label, karet, kapas dan aluminium foil, media bibit, dan media budi daya.

\section{Pelaksanaan Penelitian}

\section{Penelitian Lapangan}

Penelitian lapangan dilakukan untuk; pengamatan karakter morfologi tubuh buah; pengamatan subtrat tempat tumbuh dan sifat hidup; pengambilan jejak spora dan isolasi tubuh buah, mengumpulkan material hidup dan material herbarium. Pengambilan sampel di lapangan dilakukan dengan mengunakan metode searching dengan modifikasi jalur menggunakan petak contoh yang mengacu kepada Pollard dan Yates (1995).

\section{a. Pengamatan Morfologi Tubuh Buah}

Pengamatan morfologi dilakukan dengan metode deskriptif berdasarkan Bougher dan Syme (1998). Terhadap sampel makrofungi yang ditemukan di lapangan dilakukan pengamatan bentuk tubuh buah, ukuran, warna, tekstur, sifat hidup (sendirisendiri atau berkelompok),jumlah individu dan untuk yang berkoloni jumlah koloni, substrat tumbuh (pohon atau ranting hidup,pohon atau ranting mati, tanah, serasah atau substrat lain) dan difoto. Di samping itu dilakukan pengukuran faktor lingkungan seperti suhu (thermometer), $\mathrm{pH}$ tanah ( $\mathrm{pH}$ meter), dan kelembaban udara (hygrometer). Data faktor lingkungan ini diambil dari pagi hari sampai selesai pengambilan sampel.

\section{b. Pembuatan Jejak Spora}

Jejak spora dibuat dengan mengacu pada Leonard (2010), dengan cara, memotong bagian tudung atau carpopora dari tubuh buah, kemudian diletakkan dengan posisi telungkup di atas kertas karton dua warna (gelap dan 
terang) yang sudah disiapkan di dalam wadah (kotak). Dibiarkan sampai terbentuk jejak spora. Jejak spora yang terbentuk kemudian dimasukkan ke dalam botol yang berisi larutan lactophenol, selanjutnya diamati di laboratorium untuk melihat bentuk sporanya.

\section{c. Isolasi Tubuh Buah}

Isolasi tubuh buah dilakukan terhadap makrofungi yang berpotensi sebagai bahan pangan, tujuannya untuk mendapatkan kultur isolat yang nantinya dilakukan budi daya di laboratorium. Cara pengambilan tubuh buah mengacu pada Bougher dan Syme (1998) dengan cara; bagian dalam dari tangkai tubuh buah dibuka atau dibelah, kemudian diambil menggunakan pingset dan ditanamkan ke dalam media PDA, selanjutnya diinkubasi pada suhu kamar sampai koloninya tumbuh. Untuk sampel makrofungi yang berupa lembaran tipis seperti jamur kuping (Volvariella volvacea), pengambilan tubuh buah dilakukan dengan cara; bagian tubuh yang berupa lembaran dipotong dan disterilkan dengan menggunakan alkohol 70\%, selanjutnya dibilas dengan akuades steril, kemudian diambil mengunakan pingset dan ditanamkan ke dalam media PDA, diinkubasikan pada suhu kamar sampai koloninya tumbuh.

Semua pekerjaan yang terkait dengan isolasi tubuh buah baik dari tangkai atau dari lembaran harus dikerjakan secara steril dan aseptis, mulai dari alat yang digunakan, media dan cara isolasinya, untuk menjaga supaya tidak terjadi kontaminasi dari luar.

\section{d. Pembuatan Material Herbarium}

Material hebarium dibuat dengan cara: untuk tubuh buah yang teksturnya lunak dibuat herbarium basah, diambil tubuh buah makrofungi secara hati-hati dan jangan sampai patah, kemudian dimasukkan ke dalam botol yang berisi alkohol $70 \%$ dan formalin $4 \%$, ditutup rapat. Untuk tubuh buah yang teksturnya keras atau kenyal tidak dimasukkan dalam botol tetapi dibuat herbarium kering dengan cara mengeringkan sampel tubuh buah jamur dalam oven pada suhu $50^{\circ} \mathrm{C}$ atau langsung dijemur dengan terik matahari, sampai diperoleh spesimen herbarium kering, kemudian dimasukkan ke dalam kantongkantong kertas sesuai ukur spesimen.

Terhadap kedua jenis hebarium yang dibuat (herbarium basah dan herbarium kering), diberi label atau identitas sementara pada bagian luar botol atau kantong yang digunakan. Selanjutnya di laboratorium dilengkapi identitasnya. Identitas yang dicantumkan adalah; nama latin, nama daerah atau lokal, habitat, sifat hidup (parasit atau saprofit), warna, ciri-ciri spesifik, nama kolektor, lokasi ditemukan dan nomor koleksi.

\section{Penelitian di Laboratorium}

a. Pengamatan Morfologi Tubuh Buah Lebih Lanjut dan Pengamatan Spora.

Pengamatan tubuh buah lebih lanjut ini dilakukan untuk melekapi data-data lapangan yang belum tuntas, seperti pengamatan terhadap lamella dan pori (bentuk, ukuran, kedudukan), ciri-ciri lain lain dari tubuh buah 
Noverita, dkk: Keanekaragaman dan Potensi Jamur Makro di Kawasan Suaka Margasatwa Bukit Rimbang Bukit Baling (SMBRBB) Propinsi Riau, Sumatera

yang harus dibantu dengan menggunakan lup dan mikroskop. Sampel yang digunakan untuk pengamatan tubuh buah lanjut ini berasal dari sampel yang sudah dibikin herbarium, karena jamur tidak bisa bertahan lama bila tidak diawetkan kecuali yang teksturnya liat dan keras.

Spora yang diamati adalah spora hasil dari pembuatan jejak spora. Untuk pengamatan spora digunakan mikroskop sampai pembesaran 100X. Yang diperhatikan dalam pengamatan jejak spora ini antara lain, bentuk, ukuran, dan ornamen-ornamen lain pada spora tersebut.

\section{b. Identifikasi makrofungi}

Identifikasi jamur dilakukan berdasarkan data dari hasil pengamatan lapangan dan data dari hasil pengamatan laboratorium yang meliputi; sifat (parasit, saprofit), keberadaan tumbuh (sendiri atau koloni), substrat tempat tumbuh (kayu, ranting hidup atau mati, serasah, tanah), bentuk tubuh buah, warna, tekstur, kedudukan tangkai, komponen lain penyusun tangkai, ciri lain penyusun lamela, pori atau bagian lain penghasill spora, bentuk spora, ukuran, warna dan ornamen lainnya pada spora, dan ciri-ciri spesifik lainnya. Data yang diperoleh ini selanjutnya dicocokkan dengan buku-buku identifikasi makrofungi, sampai ditemukan nama jenisnya. Buku rujukan untuk identifikasi yang digunakan antara lain adalah; Guide To Mushrooms (Pacioni 1994), Working with Mycorrhiza in Foresty and Agriculture
(Brundrett \& Baugher 2008), How To Identify Mushrooms To Genus I (Largent,1973), Agaric Flora of The Lesser Antilles (Pegler, 1983), dan A Preliminary Polypore Flora of East Africa (Ryvardern and Johansen, 1980).

\section{c. Pengelompokkan Potensi Jamur}

Potensi jamur yang ditemukan dikategorikan ke dalam dua kelompok, yaitu sebagai bahan pangan dan sebagai bahan obat pada tiap kawasan berdasarkan diskusi dengan masyarakat, literatur dan dengan memperhatikan kondisi di sekitar jamur yang ditemukan.

\section{Analisis Data}

\section{Keanekaragaman Jenis Makrofungi}

Untuk mengetahui indeks keanekaragaman jenis jamur pada setiap habitat digunakan rumus Shannon-Winner (Magurran, 2004).

\section{Indeks Nilai Penting}

Guna mengetahui tingkat penguasaan jenis dalam komunitas dihitung nilai penting dari masing-masing jenis yang ada. Penghitungan nilai penting mengacu pada Kusmana, (1997).

\section{HASIL DAN PEMBAHASAN}

\section{Lokasi dan Kondisi Lingkungan Penelitian}

Penelitian di Kawasan Suaka Margasatwa Bukit Rimbang Bukit Baling (SMBRBB) Riau ini dilakukan di lima lokasi berbeda, yaitu Kawasan Suaka Marga Satwa Rimbang Baling (SMRB), Stasiun Subayang, Sungai Batu Dinding, Desa Muara Bio, dan Desa Tanjung Belit

(Gambar 1). 


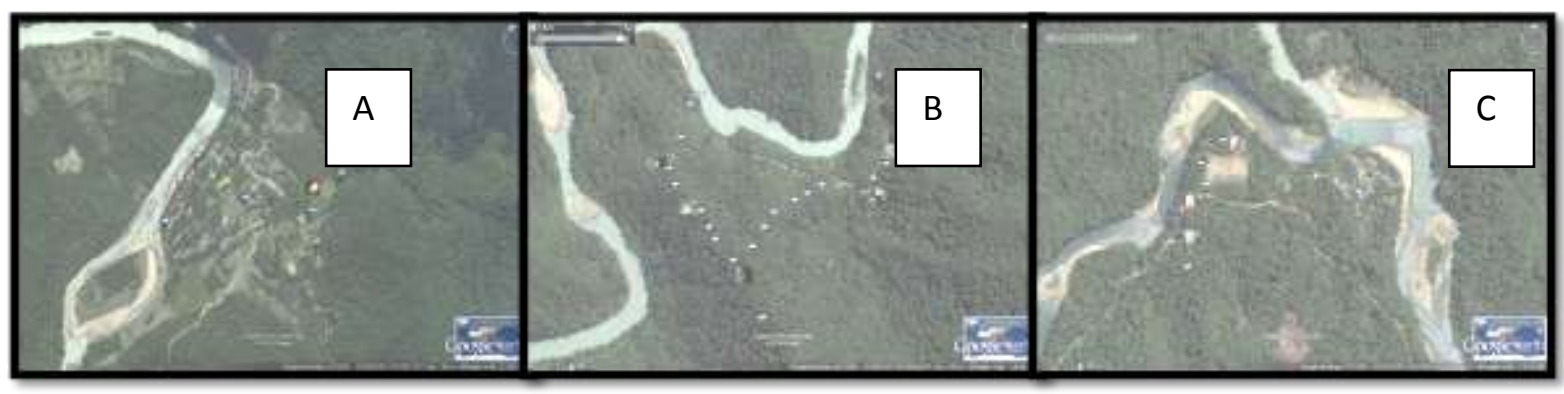

Gambar 1. Peta lokasi penelitian ; A. Desa Tanjung Belit; B. Kawasan SMRB, Subayang dan Sungai Batu Dinding; C. Desa Muara Bio.

Tabel 1. Kondisi lingkungan tiap lokasi pengambilan data.

\begin{tabular}{ccccc}
\hline Lokasi & pH & Suhu (Celcius) & Kelembaban (\%) & Cahaya \\
\hline St. Subayang & 7 & $15-19$ & $54-65 \%$ & $192 \mathrm{~A}-807 \mathrm{~A}$ \\
Sungai BatuDinding & $7-7,1$ & $21-22$ & $46-62 \%$ & $332 \mathrm{~A}-1396 \mathrm{~A}$ \\
Kawasan SMRB & 7 & $13-21$ & $49-67 \%$ & $275 \mathrm{~A}-479 \mathrm{~B}$ \\
DesaMuara Bio & 7 & $18-24$ & $39-64 \%$ & $474 \mathrm{~A}-716 \mathrm{~B}$ \\
DesaTanjungBelit & 7 & $16-20$ & $34-65 \%$ & $162 \mathrm{~A}-913 \mathrm{~B}$ \\
\hline
\end{tabular}

Terdapat beberapa perbedaan kondisi lingkungan pada kelima lokasi penelitian ini. Stasiun Subayang dan Kawasan SMRB lebih tertutup (ternaung) oleh berbagai jenis tumbuhan, namun jenis tumbuhan dan kondisi lantai hutannya sangat berbeda. Sementara Sungai Batu Dinding, Desa Mura Bio dan desa Tanjung Belit lebih terbuka. Kondisi kelima lokasi ini dapat dicerminkan dari kondisi lingkungannya yang sudah di lakukan selama penelitian (Tabel 1.).

Terdapat beberapa perbedaan kondisi lingkungan di masing-masing lokasi penelitian, hal tersebut sangat dipengaruhi oleh keberadaan tumbuhan sebagai penyusun vegetasi, ketinggian dan struktur tanah di lokasi tersebut. St. Subayang merupakan daerah yang teduh, karena banyak ditumbuhi oleh berbagai jenis tumbuhan terutama tumbuh besar dengan tutupan tajuk yang rapat, dan sebagian dari lohasi ini berada di pinggir sungai Sebayang. Sungai Batu Dinding berada berseberangan dari St. Subayang, lokasi ini lebih terbuka, berupa tebing-tebing yang cukup curam dan berbatuan, vegetasinya umumnya berupa tumbuhan semak dan perdu, jarang sekali tumbuhan besar. Desa Mura bio dan Desa Tanjung Belit merupakan dua desa yang ditempati penduduk, pedesaannya lebih terbuka, tidak banyak ditemukan tumbuhan besar, kecuali di pekarangan atau di perkebunan penduduk sekitar.

Kelembaban, suhu, dan $\mathrm{pH}$ secara ekologis merupakan faktor lingkungan yang penting untuk pertumbuhan jamur makro. Kelembaban yang dibutuh untuk pertumbuhan jamur makro berkisar antara 50\% - 70\% (Deacon, 1984), kisaran suhu pertumbuhan 
Noverita, dkk: Keanekaragaman dan Potensi Jamur Makro di Kawasan Suaka Margasatwa Bukit Rimbang Bukit Baling (SMBRBB) Propinsi Riau, Sumatera

antara $22^{\circ} \mathrm{C}-35^{\circ} \mathrm{C}$ (Arif et al., 2007), dan nilai $\mathrm{pH}$ secara umum berkisar antara $\mathrm{pH} 5,5-\mathrm{pH}$ 7 (Chang dan Miles,2009).

Selain dari tiga faktor lingkungan tersebut di atas ( $\mathrm{pH}$, suhu dan kelembaban), intensitas cahaya juga mempengaruhi pertumbuhan jamur makro. Biasanya jamur untuk pertumbuhannya membutuhkan intensitas cahaya yang rendah. Intensitas cahaya yang tinggi akan menghambat pertumbuhan jamur karena akan menghambat pembentukan struktur reproduksinya. Besar kecilnya intensitascahayadi suatu lokasi penelitian sangat dipengaruh ioleh tutupan tajuk (kanopi) dari tumbuhan yang ada dilokasi pertumbuhan jamur makro tersebut.

\section{Komposisi Jenis}

Total jenis jamur yang ditemukan secara keseluruhan terdiri atas 138 jenis, 52 marga dan 37 suku Jenis-jenis yang ditemukaan tersebut didominasi oleh Filum Basidiomycota, yaitu sebanyak 131 jenis, sisanya 6 jenis Ascomycota, dan 1 jenis Myxomycota (Tabel Lampiran).

Umumnya, jamur makro yang ditemukan di lingkungan termasuk ke dalam filum Basidiomycota, dan biasanya makrofungi ini lebih dikenal dengan istilah jamur atau cendawan. Sementara filum Ascomycota umumnya berukuran mikroskopis dan hanya sebagian kecil yang berukuran makroskopis. Jenis lain yang juga sering ditemukan di alam dalam jumlah yang sedikit adalah dari Filum Myxomycota (jamur lendir).

Filum Basidiomycota memiliki tubuh buah (basidiokarp) yang sebagian besar berukuran makroskopik sehingga dapat dilihat dengan mata telanjang (Ganjar et al. 2006). Basidiokarp terdiri, atas tudung (Cap), bilah (gill) atau pori, tangkai (stipe), kadang-kadang terdapat cincin (annulus), sisik dan volva (scale) (Mureli et al., 2012). Pada lamela atau pori ini, terbentuk banyak basidium yang akan menghasilkan spora (basidiospora), berjumlah empat berada di luar basidium. Sementara filum Ascomycota dicirikan dengan spora (akospora) yang terdapat di dalam kantung yang disebut askus. Askus. Setiap askus biasanya memiliki 2-8 askospora. Kebanyakan ascomycetes bersifat mikroskopis, sebagian kecil bersifat makroskopis yang memiliki tubuh buah (Gandjar et al., 2006).

\section{Keanekaragaman Jenis}

Terdapat $\quad$ Indeks keanekaragaman jenis $\left(\mathrm{H}^{\prime}\right)$ jamur makro di lima lokasi pengamatan.(Gambar 2).

Indeks Keanekaragaman Jenis makrofungi di lima lokasi pengamatan berkisar antara 2,975\% sampai dengan $3,360 \%$. Indek keanekaragaman tertinggi ditemukan di Stasiun Subayang (3,360\%), yang diikuti oleh Kawasan SMRB (3,357\%). Indeks keanekaragaman terendah di Sungai Batu Dinding $(2,975 \%)$. 


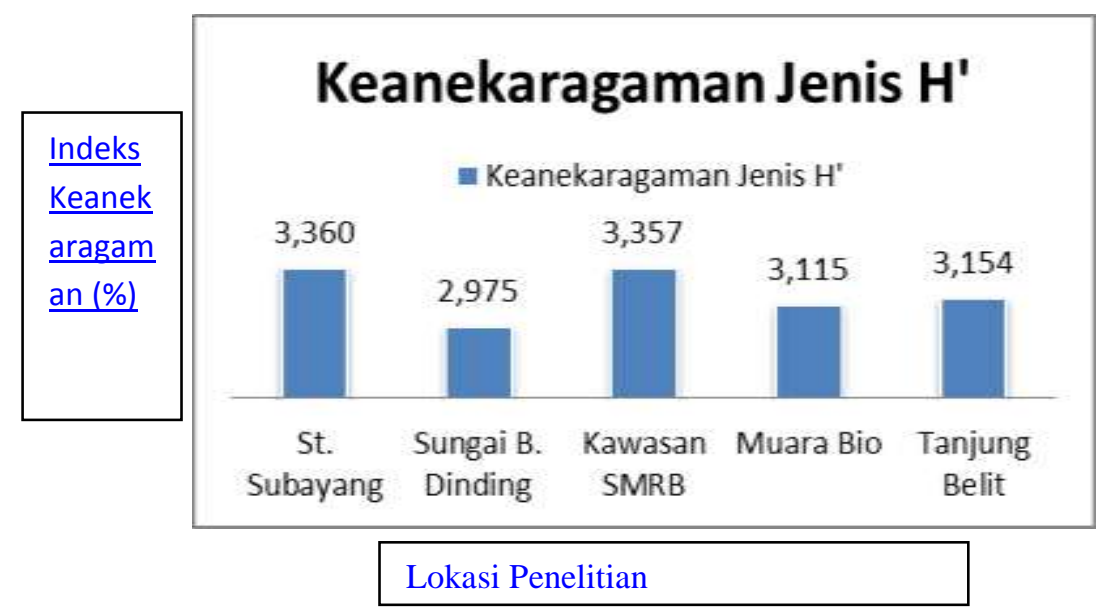

Gambar 2. Indeks keanekaragaman Jamur Makro di lima lokasi pengamatan di kawasan Suaka Margasatwa Bukit Rimbang Bukit Baling (SMBRBB) Riau.

Tingginya indeks keanekaragaman di Stasiun Subayang dan Kawasan SMRB terutama disebabkan oleh kondisi lingkungan yang mendukung (Tabel 1), dan substrat tempat tumbuh yang lebih bervariasi di bandingkan dengan lokasi yang lain. Lokasi Stasiun Subayang dan lokasi SMRB disusun oleh vegetasi tumbuhan yang cukup rapat dan banyak ditemukan pohon, cabang dan ranting kayu mati, dan dilantai hutan banyak ditemukan serasah. Kondisi tersebut sangat memungkinkan untuk tumbuhnya berbagai jenis jamur. Sedang di lokasi Sungai Batu Dinding sangat terbuka, dan vegetasi tumbuhan sangan sedikit, bahkan lebih didominasi tumbuhan semak dan herba. Namun bila dikaitkan dengan uji Shannon-Winner, indeks keanekaragaman jenis pada masing-masing kawasan tersebut termasuk ke dalam kategori sedang. Magurran (2004) yang menyatakan bahwa kisaran nilai indeks keanekaragaman (H') antara 0-2,302 tergolong rendah, $H^{\prime}$ antara 2,302-6,907 tergolong sedang, dan H' lebih dari 6,907 tergolong tinggi.

Odum (1996), menyatakan bahwa keanekaragaman mencakup dua hal penting yaitu banyaknya jenis yang ada dalam suatu komunitas dan kelimpahan dari masing-masing jenis tersebut, sehingga semakin kecil jumlah jenis dan variasi jumlah individu tiap jenis atau ada beberapa individu yang jumlahnya jauh lebih besar, maka keanekargaman suatu ekosistem akan mengecil.

\section{Indeks Keseragaman Jenis Jamur}

\section{Makro (E)}

Indek keseragaman jenis jamur makro di lima lokasi pengamatan dapat dilihat pada Gambar 3. 


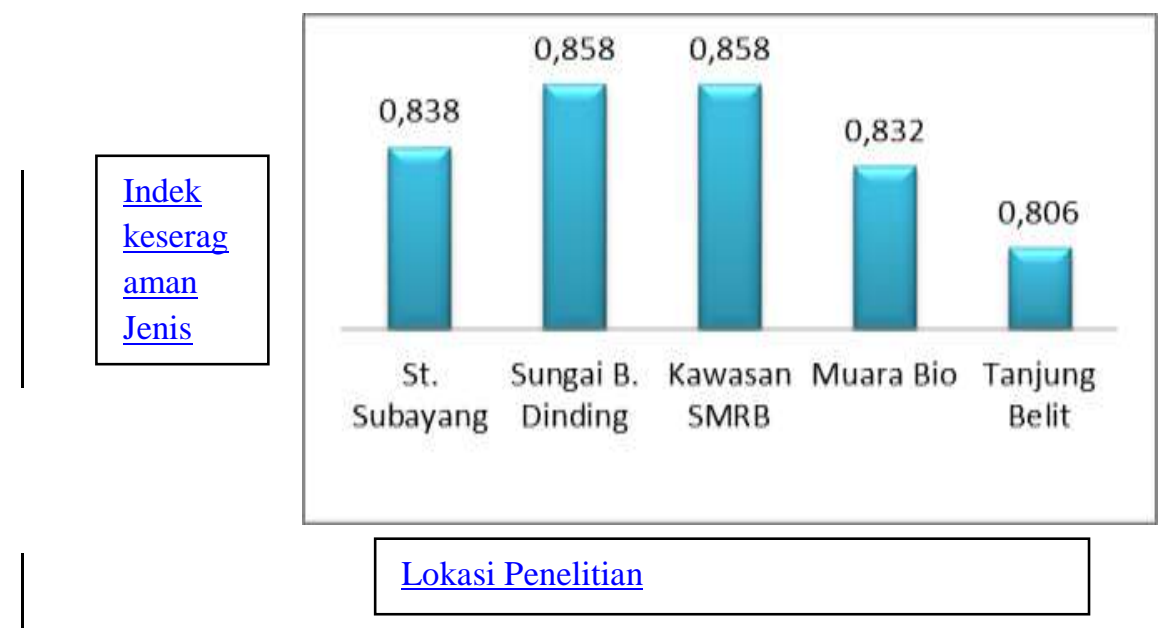

Gambar 3. Nilai indeks keseragaman jenis Jamur Makro di lima lokasi Kawasan Suaka Margasatwa Bukit Rimbang Bukit Baling (SMBRBB) Riau.

Gambar 3 memperlihatkan bahwa nilai Indeks Keseragaman Jenis jamur makro di lima kawasan tersebut berkisar dari 0,806 sampai dengan 0,858. Indeks Keseragaman Jenis tertinggi ditemukan di Sungai Batu dinding dan Kawasan SMRB $(0,858)$, dan yang terendah di Desa Tanjung Balit (0.806). Indeks keseragaman jenis jamur makro di lima kawasan ini tergolong tinggi. Menurut Krebs (1985), nilai indeks keseragaman digolongkan menjadi 3 , yaitu $0<\mathrm{E} \leq 0,4$, maka keseragaman populasi kecil; bila $0,4<\mathrm{E}$ $<0,6$, maka keseragaman populasi sedang; dan bila $\mathrm{E} \geq 0,6$, maka keseragaman populasi tinggi. Tingginya indek keseragaman jenis jamur makro di lima lokasi ini menunjukkan tidak beragamnya substrat tempat tumbuh jamur makro, terutama batang dan ranting kayu mati serta serasah. Disamping itu secara umum lokasi penelitian ini cendrung terbuka, kecuali di St. Subayang. Kondisi ini akan menyebabkan hanya jenis-jenis tertentu yang mampu tumbuh dan beradaptasi dengan baik.

Lodge dan Cantrell (1995) dan Hanson (2008), menyatakan bahwa pemanfaatan sumber daya dalam hal ini nutrien, dari suatu sistem seperti di dalam tanah diketahui memiliki beberapa tahapan, dimana masingmasing tahapan tersebut terjadi suatu kekhususan atau dominansi organisme pada tingkatan tertentu, baik dari jenis itu sendiri ataupun jenis lainnya sesuai dengan kondisi lingkungan yang terjadi pada saat itu .

\section{Pengelompokan Potensi Jamur Makro}

Kehadiran jamur makro di alam sangat penting dalam menunjang kehidupan di lingkungan baik bagi tumbuhan, hewan dan manusia. Di lingkungan jamur makro ini penting sebagai mengurai (dekomposisi) senyawa komplek menjadi bentuk yang sederhana, hasil penguraiannya sebagian kecil dimanfaatkan sebagai sumber nutrisi untuk pertumbuhannya dan yang lainnya 
dimanfaatkan oleh organisme di sekitarnya, terutama tumbuhan. Untuk jenis jamur makro yang bersifat mikoriza, kehadirannya sangat dibutuhkan oleh tumbuhan di sekitarnya terutama tumbuhan berkayu, untuk membantu dalam penyerapan air dan mineral dari dalam tanah. Selain dari itu jamur makro juga dapat dimanfaatkan oleh manusia sebagai sumber bahan pangan dan bahan obat.

Hasil penelitian ini menemukan sebanyak 86 jenis jamur makro punya potensi, yang terdiri dari 66 jenis berpotensi obat dan sebanyak 32 jenis berpotensi pangan (Tabel Lampiran 2). Jumlah makrofungi yang ditemukan dalam penelitian yang berpotensi sebagai bahan obat lebih banyak dibandingkan dengan yang berpotensi sebagai bahan pangan. Adanya perbedaan ini sangat terkait pada subtrat tempat tumbuh serta lingkungan tubuh dari makrofungi tersebut. Pada umumnya, jamur yang berpotensi sebagai bahan obat umumnya dapat tumbuh pada substrat yang lebih luas, dan bahkan mampu tumbuh pada kondisi lingkungan yang eksrim bagi makrofungi secara umum. Hal tersebut dapat dilihat dari indeks keanekaragaman jamur yang berpotensi sebagai bahan obat ini dibandingkan dengan yang berpotensi sebagai bahan pangan pada masing-masing lokasi penelitian selalu mendominasi (Gambar 4).

Indeks Keanekaragaman jenis jamur makro berpotensi obat paling tinggi di kawasan SMRB, selanjutnya diikuti oleh kawasan Muara Bio, dan Sungai Batu Dinding (Gambar 4). Beberapa contoh jenis-jenis foto jamu makro berpotensi sebagai bahan obat yang ditemukan di lokasi penelitian ditampilkan pada gambar 5 .

\section{Di negara Asia Timur penggunaan} jamur sebagai obat sudah lama diketahui, jenisnya antara lain adalah Lentinus dan Ganodermalucidum. Jamur tersebut dapat dimanfaatkan sebagai obat-obatan karena mengandung beberapa senyawa kimia dalam tubuh buahnya. Gnodermin (asam ganodermat) pada jamur yang dihasilkan Ganoderma spp. dapat membantu penetralan atau penurunan senyawa penyebab berbagai penyakit (Hudler, 1998).

Masyarakat di sekitar Kawasan Bukit Rimbang Bukit Baling sudah memanfaatkan beberapa jenis jamur ini sebagai bahan obat, informasi ini lansung diperoleh dari masyarakat setempat dan orang pintar (paramedis) yang dipercaya oleh masyarakat di kawasan tersebut. Jenis jamur yang dimanfaatkan masyarakat, antara lain: Pleurotus spp. untuk kembung, Polyporus untuk obat bisul di kulitGanoderma lucidum untuk obat meriang. Jenis lain yang juga digunakan adalah Picnoporus, dan Cookeina.

Jamur yang berpotensi pangan yang ditemukan di kawasan tersebut antara lain adalah Agaricus sp., Auricularia auricula, Auricularia delicata, Auricularia polytricha, Calvatia sp., Hygroporus sp., Inonotus sp., 
Noverita, dkk: Keanekaragaman dan Potensi Jamur Makro di Kawasan Suaka Margasatwa Bukit Rimbang Bukit Baling (SMBRBB) Propinsi Riau, Sumatera

Lentinus sajor caju., Lentinus squamolosus;

Pleurotus ostreatus; Cookeinasuicipes;

Schizophyllumcommune., Tramella fuciformis, dan Volvariella volvacea (Gambar 6).
Beberapa jenis dari jemur tersebut sudah dimanfaatkan oleh masyarakat setempat, yaitu Auricularia auricula, Lentinus, Sarcoscypha , dan Schizophyllum commune.

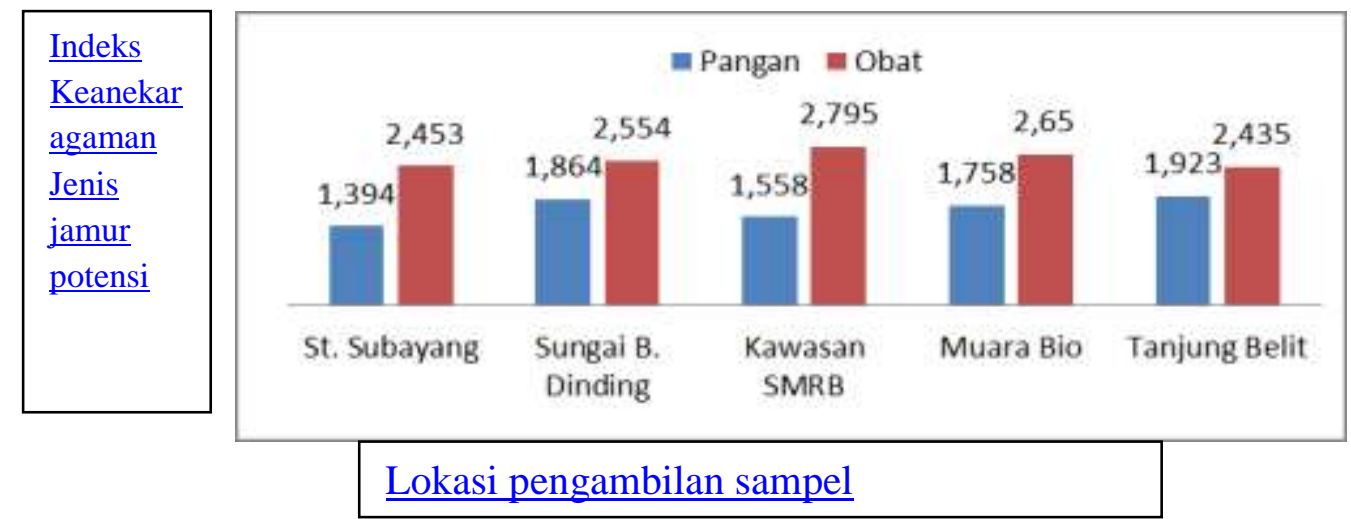

Gambar 4. Indeks keanekaragaman jenis jamur potensi pangan dan obat di lima lokasi penelitian berbeda.

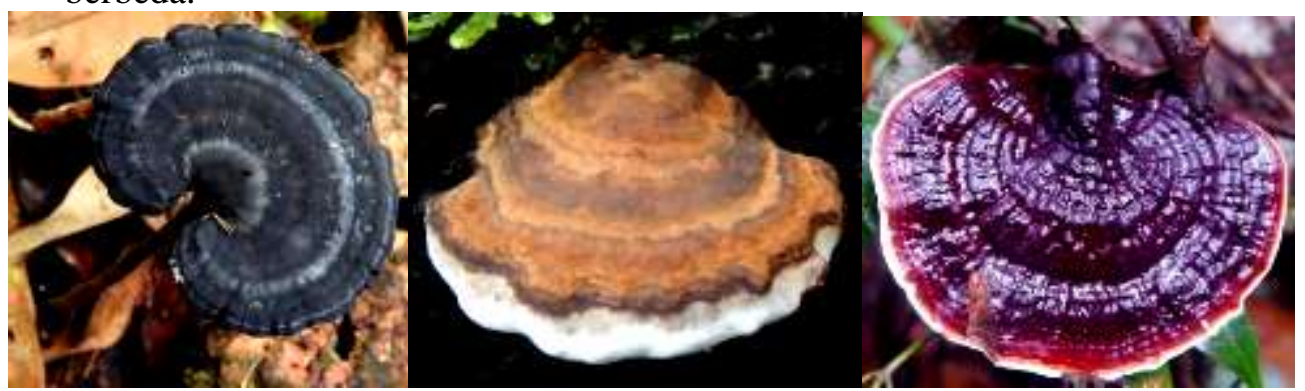

Amaroderma sp

Ganoderma applanatum

Ganoderma lucidum

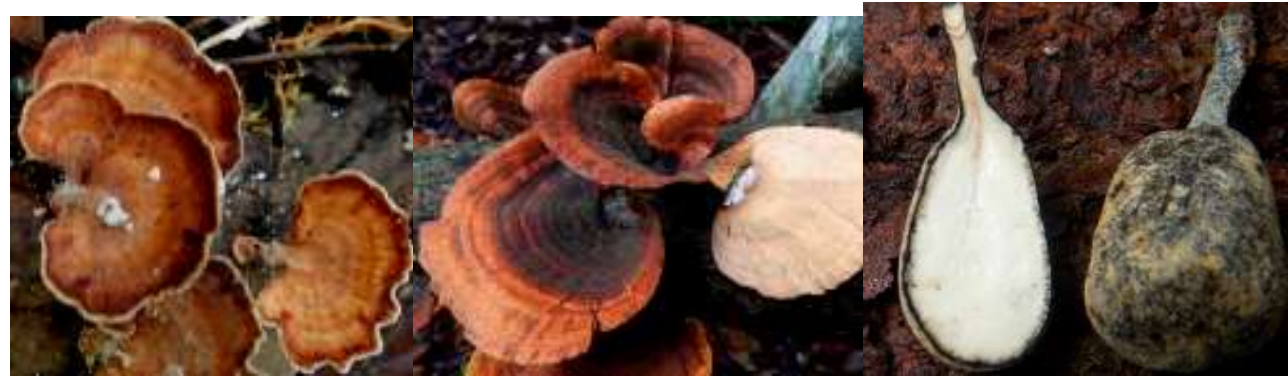

Microprus afinitis

Trametes sp

Xylaria sp.

Gambar 5. Contoh Makrofungi berpotensi sebagai bahan obat yang ditemukan di lokasi penelitian (Dokumentasi Noverita, 2016).

Beberapa jenis dari jamur yang ditemukan dalam penelitian sama dengan yang ditemukan Noverita dkk (2017) di Kawasan Cagar Alam Lembah Anai dan Cagar Alam Batang Palupuh Sumatera. spp., Boletellus spp., Calvatia excipuliformis, Cantharellus cibarius, Cookeinaspeciosa, Fistulinasp, Hygrocybe $\mathrm{sp} 2$

Lentinussajor-caju,

Marasmiellusramealis, Russula fragilis, Jenis yang ditemukan adalah Auricularia dan Pluteuscervinus. auricula, Auricularia delicata, Agaricus 


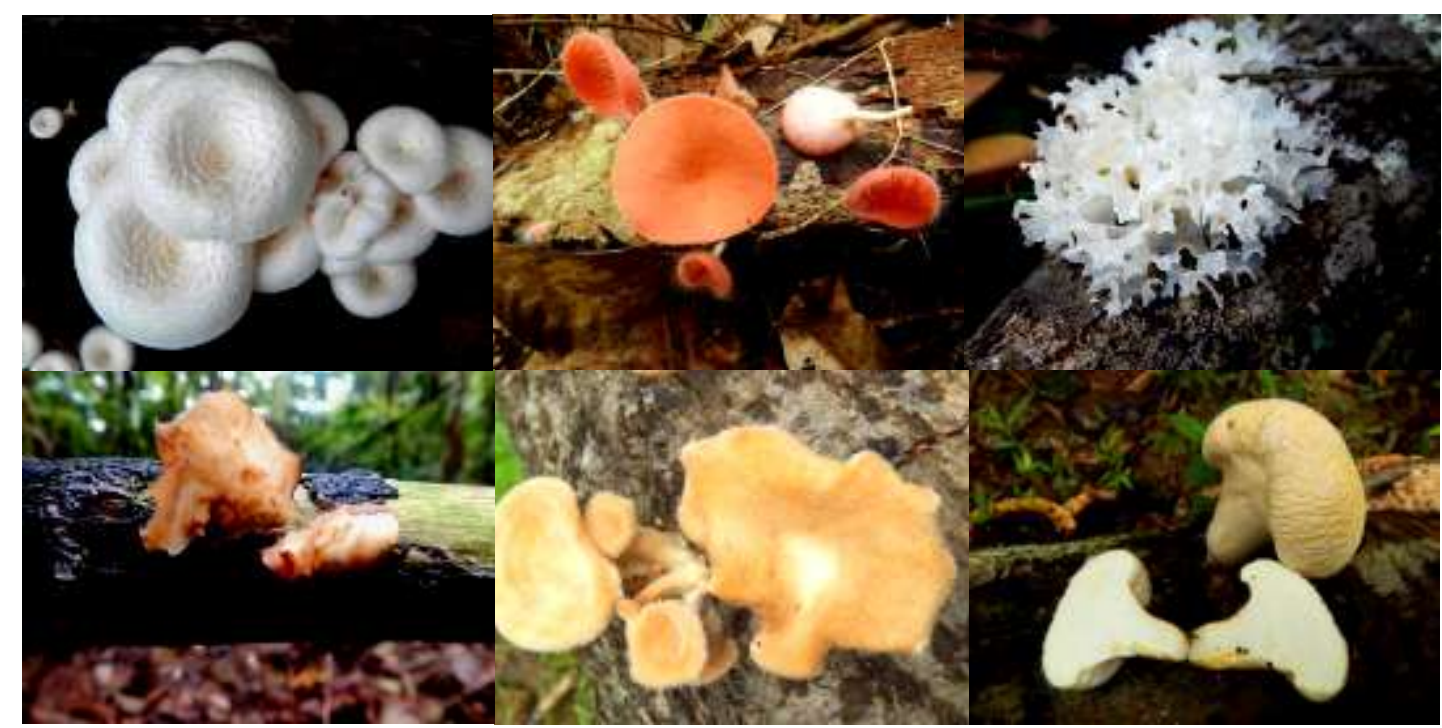

Gambar 6. Contoh Jamur Makro berpotensi sebagai bahan pangan yang ditemukan di lokasi penelitian (Dokumentasi Noverita, 2016).

Makrofungi dimanfaatkan sebagai bahan pangan karena rasanya yang enak dan kandungan gizi yang lengkap. Menurut Suriawiria (2000), komposisi kandungan kimia yang terkandung di dalam jamur tergantung pada masingmasing jenis jamur dan tempat tumbuhnya. Kandungan utama jamur makro adalah protein dan lemak, selain itu juga mengandung mineral, vitamin, dan beberapa senyawa lainnya, selanjutnya Chang dan Miles (1989) menyatakan bahwa terdapat 9-20 kandungan asam amino essensial dan kandungan lemak tidak jenuh sebanyak $72 \%$ ada di dalam jamur sehingga aman apabila dimakan. Vitamin yang terkandung dalam jamur antara lain thiamine (vitamin B1), riboflavin (vitamin B12), niasin, biotin, dan vitamin $\mathrm{C}$

\section{KESIMPULAN}

Setelah dilakukan penelitian tentang "Keanekaragaman dan Potensi Budi Daya Makrofungi di Kawasan Suaka Margasatwa Bukit Rimbang Bukit Baling (SMBRBB) Riau", maka dapat ditarik kesimpulan sebagai berikut;

1. Diperoleh sebanyak 138 jenis, 52 marga dan 37 suku jamur makro ipada lima lokasi penelitian di sekitar Kawasan SuakaMargasatwa Bukit Rimbang Bukit Baling (SMBRBB).

2. Indeks keanekaragaman jenis pada masing-masing jalur termasuk ke dalam kategori sedang. 
Noverita, dkk: Keanekaragaman dan Potensi Jamur Makro di Kawasan Suaka Margasatwa Bukit Rimbang Bukit Baling (SMBRBB) Propinsi Riau, Sumatera

3. Indeks keseragaman jenis pada masing-masing jalur termasuk ke dalam kategori tinggi.
4. Diperoleh sebanyak 63 jenis jamur makro berpotensi sebagai bahan obat, 34 jenis sebagai bahan pangan.

\section{DAFTAR PUSTAKA}

Arif A, M Muin, T Kuswinanti, dan V Harfiani. 2007. Isolasi dan identifikasi Jamur Kayu dari hutan Pendidikan dan Latihan Tbo-tabo Kecamatan Bungoro Kabupaten Pangkep. Jurnal Perennial. 3(2): 49 -54 .

Aryantha IP. 2005. Strategi risert dan pengembangan dalam pengelolaan potensi biodiversitas. Workshop Pengelolaan Potensi Biodiversitas, LPIU-FK8PT - Universitas Udayana, Kampus Bukit Jimbaran, Denpasar-Bali, 14-15 November 2005

Bougher NL and Sume K. 1998. Fungi of Southern Australia. Nederlands Westeen Australia 6907: University of Western Australia Press.

Brundrett M, Bougher N, Dell, Grove BT, and Malajczuk N. 1995. Working with mycorrhiza in foresty and agriculture. Australia: ACIAR Monograph .

Brundrett MC. 2008. Mycorrhizal associations: the web resource. Online at http://mycorrhizas.info/index.html.

Chang ST and PG Miles. 1989. Edible Mushrooms and Their Cultivation. Boca Raton, FL: CRC Press, 345 pp.

Deacon JW. 1997. Modern Mycology. 3rd ed., Blackwell Science, Willey. Edinburgh.

Ermanita V, Mades Fifendy, dan Yosmed Hidayat . 2018. Jenis-jenis Jamur Makroskopis yang terdapat pada perkebunan kelapa sawit PTPN VI Unit Usaha Ophirpasaman Barat Program Studi Pendidikan Biologi STKIP PGRI SUMBAR.
Faisal A, Noverita, dan H Rusmendro. 2007. Kelimpahan dan kenekaragaman Jamur Makroskopis bermanfaat pada ketinggian berbeda di Pusat Pendidikan Konservasi Alam Bodogol (PPKAB), Taman Nasional Gunung Gede Pangrango Jawa Barat. Jakarta: Fakultas Biologi Universitas Nasional.

Hawksworth DL. 2001. The magnitude of fungal divers: the 1.5 million species estimate revisited. Mycol. Res. 105:1422-1432.

Hilman dan Romadoni. 2001.

Hudler GW. 1998. Magical mushrooms, mischievous mould. USA: Princeton University Press, pp 248.

Krebs C Z. 1985. Ecology : the experimental analysis of distribution and abundance, third Edition. New York : Harper and Row Publisher Inc.

Kusmana C. 1997. Metode survey vegetasi. Bogor: PT. Penerbit Insitut Pertanian Bogor.

Kuswinanti K dan Rahmawati. 2008. Isolasi dan identifikasi Jamur Kayu dari hutan Pendidikan Universitas Hasanuddin Di Bengo-Bengo Kecamatan Cenrana Kabupaten Maros. Jurnal Perennial, 5(1) : 1522 Oktober 2008

Largent D. 1973. How to Identify Mushrooms to Genus I: Macroscopic Features. Mad River Press. Inc. Route.Eureka California.

Leonard PL. 2010. Guide to collecting and preserving fungal specimens for the Queensland Herbarium. Brisbane: Queensland Herbarium, Department of Environment and Resource Management. 
Magurran AE. 2004. Measuring Biological Diversity. Australia: Blackwell Publishing Company.

Noverita N, Sinaga E, Setia TM. 2017. Jamur Makro berpotensi pangan dan obat di Kawasan Cagar Alam Lembah Anai dan Cagar Alam Batang Palupuh Sumatera. Jurnal Mikologi Indonesia, 1(1).

Odum EP. 1996. Dasar-dasar ekologi. Yogyakarta: Gadjah Mada University Press.

Pacioni G. 1994. Simon \& Schuster's Guide to Mushrooms. New York: A Fireside Book Published By Simon \& Schuster Inc.

Pegler DN. 1983. AgaricFlora of the Lesser Antilles. London: Her Majesty's Stationery office,

Pollard E dan Yates T J. 1995. Conservation Biology Series. Monitoring Butterfly for Ecology and Conservation. London UK: Chapman and Hall.

Ryvardern L and Johansen I.1980. A preliminary polypore flora of East Africa. Fungiflora-Oslo-Norway.

Sari PHM, Nazip K, dan Dayat E. 2016. Jenis-Jenis

Basidiomycota
Kawasan Air Terjun Curug Pandan

Kabupaten Lahat serta sumbangannya pada pembelajaran Biologi di SMA. Jurnal Pembelajaran Biologi, Kajian Biologi dan pembelajarannya.Universitas Sriwijaya, 3 (1).

Suriawiria HU. 2000. Jamur konsumsi dan berkhasiat obat. Jakarta: Papas Sinar Sinanti.

Tampubolon SDBM, Utomo B, dan Yunasfi. 2012. Keanekaragaman Jamur Makroskopis di Hutan Pendidikan Universitas Sumatera Utara Desa Tongkoh Kabupaten Karo Sumatera Utara . Skripsi. Program Studi Kehutanan, Fakultas Pertanian, Universitas Sumatera Utara

Tyaningsih S, Nursyahra, dan Abizar. 2014. Inventarisasi Jamur Makroskopis di kawasan penyangga (Buffer Zone) perkebunan kelapa sawit Kiliran Jao Kecamatan Kamang Baru Kabupaten Sijunjung Sulis . Skripsi. Program Studi Pendidikan Biologi STKIP PGRI Sumatera Bara 
Noverita, dkk: Keanekaragaman dan Potensi Jamur Makro di Kawasan Suaka Margasatwa Bukit Rimbang Bukit

Baling (SMBRBB) Propinsi Riau, Sumatera

\section{Lampiran}

Tabel Lampiran: Jenis-jenis jamur makro yang ditemukan di lokasi penelitian beserta potensinya

\begin{tabular}{|c|c|c|c|c|}
\hline No & Jenis & Suku & Filum & potensi \\
\hline 1 & Agaricus sp. & Agaricaceae & Basidiomycota & Pangan \\
\hline 2 & Amanita citrina. & Amanitaceae & Basidiomycota & - \\
\hline 3 & Amanita rooseveltensis & Amanitaceae & Basidiomycota & - \\
\hline 4 & Amauroderma rugosum & Ganodermataceae & Basidiomycota & Obat \\
\hline 5 & Amauroderma sp1. & Ganodermataceae & Basidiomycota & Obat \\
\hline 6 & Auricularia auricula & Auriculariaceae & Basidiomycota & Pangan/Obat \\
\hline 7 & A. delicata & Auriculariaceae & Basidiomycota & Pangan/Obat \\
\hline 8 & A. polytricha & Auriculariaceae & Basidiomycota & Pangan/Obat \\
\hline 9 & Bordenzewia berkeleyi & Polyporaceae & Basidiomycota & - \\
\hline 10 & Calosera viscosa & Dacrymycetaceae & Basidiomycota & - \\
\hline 11 & Ceratiomyxa fruticulosa & Ceratiomyxaceae & Myxomycota & - \\
\hline 12 & Calvatia $\mathrm{sp}$ & Agaricaceae & Basidiomycota & Pangan \\
\hline 13 & Cookeina tricoloma & Sarcoscyphaceae & Ascomycota & Pangan/Obat \\
\hline 14 & Cookeina sulcipes & Sarcoscyphaceae & Ascomycota & Pangan Obat/ \\
\hline 15 & Coprinellus sp 1 & Agaricaceae & Basidiomycota & - \\
\hline 16 & Coprinopsis sp & Agaricaceae & Basidiomycota & - \\
\hline 17 & Craterellus sp1 & Cantharellaceae & Basidiomycota & Pangan \\
\hline 18 & Craterellus sp2 & Cantharellaceae & Basidiomycota & Pangan \\
\hline 19 & Crepidotus sulphurinus & Crepidotaceae & Basidiomycota & - \\
\hline 20 & Crepidotus mollis & Crepidotaceae & Basidiomycota & - \\
\hline 21 & Cymatoderma elegans & Meruliaceae & Basidiomycota & Obat \\
\hline 22 & Cymatoderma sp1 & Meruliaceae & Basidiomycota & Obat \\
\hline 23 & Daedalea quercina & Fomitopsidaceae & Basidiomycota & Obat \\
\hline 24 & Daldinea concentrica & Xylariaceae & Ascomycota & Obat \\
\hline 25 & Phallus indusiatus & Phallaceae & Basidiomycota & Pangan \\
\hline 26 & Entoloma $\mathrm{sp} 1$ & Entolomataceae & Basidiomycota & - \\
\hline 27 & Entoloma $\mathrm{sp} 2$ & Entolomataceae & Basidiomycota & - \\
\hline 28 & Earliella scabrosa & Polyporaceae & Basidiomycota & - \\
\hline 29 & Filoboletus manipularis & Mycenaceae & Basidiomycota & Pangan \\
\hline 30 & Fomes fomentarius & Polyporaceae & Basidiomycota & Obat \\
\hline 31 & Fomitopsis pinicola & Fomitopsidaceae & Basidiomycota & Obat \\
\hline 32 & Geastrum $\mathrm{sp}$ & Gestraceae & Basidiomycota & Obat \\
\hline 33 & Galiella celebica & Sarcosomataceae & Ascomycota & \\
\hline 34 & Ganoderma aplanatum & Ganodermataceae & Basidiomycota & Obat \\
\hline 35 & G.boneanse & Ganodermataceae & Basidiomycota & Obat \\
\hline 36 & G. lucidum & Ganodermataceae & Basidiomycota & Obat \\
\hline
\end{tabular}


Noverita, dkk: Keanekaragaman dan Potensi Jamur Makro di Kawasan Suaka Margasatwa Bukit Rimbang Bukit Baling (SMBRBB) Propinsi Riau, Sumatera

\begin{tabular}{|c|c|c|c|c|}
\hline No & Jenis & Suku & Filum & potensi \\
\hline 37 & G. neo-javanicum & Ganodermataceae & Basidiomycota & Obat \\
\hline 38 & Ganoderma sp1. & Ganodermataceae & Basidiomycota & Obat \\
\hline 39 & Gymnopilus aeruginosus & Cortinariaceae & Basidiomycota & - \\
\hline 40 & Gymnopilus luteofolius & Marasmiaceae & Basidiomycota & - \\
\hline 41 & Hapalopilus sp. & Polyporaceae & Basidiomycota & - \\
\hline 42 & Higrophorus sp. & Hygrophoraceae & Basidiomycota & - \\
\hline 43 & $\begin{array}{c}\text { Hymenochaeta } \\
\text { rubiginosa }\end{array}$ & Hymenochaetaceae & Basidiomycota & - \\
\hline 44 & Hygrocybe ceracea & Hygrophoraceae & Basidiomycota & Pangan \\
\hline 45 & Heterobasidion annosum & Bondarzewiaceae & Basidiomycota & - \\
\hline 46 & Inonotus hispidus & Hymenochaetaceae & Basidiomycota & Obat \\
\hline 47 & Laccaria $\mathrm{sp} 1$ & Hydnanglaceae & Basidiomycota & - \\
\hline 48 & Laccaria $\mathrm{sp} 2$. & Hydnanglaceae & Basidiomycota & - \\
\hline 49 & Laetiporus sulphureus & Fomitopsidaceae & Basidiomycota & Pangan \\
\hline 50 & Lentinus sajor caju & Lentinaceae & Basidiomycota & Pangan / Obat \\
\hline 51 & L. squamolosus & Lentinaceae & Basidiomycota & Pangan /Obat \\
\hline 52 & L. trigosus & Lentinaceae & Basidiomycota & Pangan/Obat \\
\hline 53 & Lentinus $\mathrm{sp}$ & Lentinaceae & Basidiomycota & Pangan / Obat \\
\hline 54 & Lenzites $\mathrm{sp}$ & Polyporaceae & Basidiomycota & Obat \\
\hline 55 & Lepiota $\mathrm{sp}$ & Agaricaceae & Basidiomycota & - \\
\hline 56 & Lycoperdon perlatum & Agaricaceae & Basidiomycota & Pangan \\
\hline 57 & Marasmiellus candidus & Marasmiaceae & Basidiomycota & Pangan \\
\hline 58 & Marasmius maxima & Marasmiaceae & Basidiomycota & - \\
\hline 59 & Marasmius scorodonius & Marasmiaceae & Basidiomycota & - \\
\hline 60 & Marasmius $\mathrm{sp} 1$ & Marasmiaceae & Basidiomycota & - \\
\hline 61 & Marasmius sp2 & Marasmiaceae & Basidiomycota & - \\
\hline 62 & Marasmius sp3 & Marasmiaceae & Basidiomycota & - \\
\hline 63 & Marasmius sp4 & Marasmiaceae & Basidiomycota & - \\
\hline 64 & Marasmius sp5 & Marasmiaceae & Basidiomycota & - \\
\hline 65 & Marasmius sp6 & Marasmiaceae & Basidiomycota & - \\
\hline 66 & Marasmius sp7 & Marasmiaceae & Basidiomycota & - \\
\hline 67 & Marasmius sp8 & Marasmiaceae & Basidiomycota & - \\
\hline 68 & Marasmius sp9 & Marasmiaceae & Basidiomycota & - \\
\hline 69 & Marasmius sp10 & Marasmiaceae & Basidiomycota & - \\
\hline 70 & Marasmius sp11 & Marasmiaceae & Basidiomycota & - \\
\hline 71 & Marasmius sp12 & Marasmiaceae & Basidiomycota & - \\
\hline 72 & Marasmius sp13 & Marasmiaceae & Basidiomycota & - \\
\hline 73 & Marasmius sp14 & Marasmiaceae & Basidiomycota & - \\
\hline 74 & Marasmius sp15 & Marasmiaceae & Basidiomycota & - \\
\hline
\end{tabular}


Noverita, dkk: Keanekaragaman dan Potensi Jamur Makro di Kawasan Suaka Margasatwa Bukit Rimbang Bukit Baling (SMBRBB) Propinsi Riau, Sumatera

\begin{tabular}{|c|c|c|c|c|}
\hline No & Jenis & Suku & Filum & potensi \\
\hline 75 & Marasmius sp16 & Marasmiaceae & Basidiomycota & - \\
\hline 76 & Marasmius sp17 & Marasmiaceae & Basidiomycota & - \\
\hline 77 & Megacollybia $\mathrm{sp}$ & Marasmiaceae & Basidiomycota & - \\
\hline 78 & Microporus afinitis & Marasmiaceae & Basidiomycota & Obat \\
\hline 79 & M. elegans & Polyporaceae & Basidiomycota & $\overline{\text { Obat }}$ \\
\hline 80 & M. xantophus & Polyporaceae & Basidiomycota & Obat \\
\hline 80 & $M$. vernicipes & Polyporaceae & Basidiomycota & Obat \\
\hline 81 & Microporus sp1. & Polyporaceae & Basidiomycota & Obat \\
\hline 82 & Microporus sp2. & Polyporaceae & Basidiomycota & Obat \\
\hline 83 & Microporus sp 3. & Polyporaceae & Basidiomycota & Obat \\
\hline 84 & Microporus sp5. & Polyporaceae & Basidiomycota & Obat \\
\hline 85 & Mycena sp1. & Polyporaceae & Basidiomycota & \\
\hline 86 & Mycena sp2. & Mycenaceae & Basidiomycota & - \\
\hline 87 & Mycena sp3. & Mycenaceae & Basidiomycota & - \\
\hline 88 & Oudemansiella canarii & Mycenaceae & Basidiomycota & Pangan \\
\hline 89 & Oudemansiella mucida & Physalacriaceae & Basidiomycota & Pangan \\
\hline 90 & Parasola $\mathrm{sp}$ & Physalacriaceae & Basidiomycota & \\
\hline 91 & Panus neostrigosus & Psathyrellaceae & Basidiomycota & Pangan/Obat \\
\hline 92 & Panus fasciatus & Polyporaceae & Basidiomycota & Pangan/Obat \\
\hline 93 & Philodendron sp. & Polyporaceae & Basidiomycota & Pangan \\
\hline 94 & Pholiota $s p$ & Marasmiaceae & Basidiomycota & - \\
\hline 95 & Pycnoporus cinnabarius & Strophariaceae & Basidiomycota & Obat \\
\hline 96 & Pleurotus ostreasus & Polyporales & Basidiomycota & Pangan \\
\hline 97 & Pluteus sp. & Pleurotaceae & Basidiomycota & Pangan \\
\hline 98 & Polyporus sp1. & Pluteaceae & Basidiomycota & Obat \\
\hline 99 & Polyporus sp2. & Polyporaceae & Basidiomycota & Obat \\
\hline 100 & Polyporus arcularius & Polyporaceae & Basidiomycota & Obat \\
\hline 101 & Polyporus sp1. & Polyporaceae & Basidiomycota & Obat \\
\hline 102 & Polyporus sp2. & Polyporaceae & Basidiomycota & Obat \\
\hline 103 & Polyporus sp3. & Polyporaceae & Basidiomycota & Obat \\
\hline 104 & Polyporus sp4. & Polyporaceae & Basidiomycota & Obat \\
\hline 105 & Polyporus sp5. & Polyporaceae & Basidiomycota & Obat \\
\hline 106 & Phyllotopsis nidulans & Polyporaceae & Basidiomycota & Obat \\
\hline 107 & Piptoporus solaniensis & Tricholomataceae & Basidiomycota & - \\
\hline 108 & Rigidoporus microporus & Polyporaceae & Basidiomycota & Obat \\
\hline 109 & Rigidoporus lignosus & Meripiliaceae & Basidiomycota & Obat \\
\hline 110 & Podoscypha parvula & Meripiliaceae & Basidiomycota & Obat \\
\hline 111 & Pleurocybella $\mathrm{sp}$ & Meruliaceae & Basidiomycota & - \\
\hline
\end{tabular}


Noverita, dkk: Keanekaragaman dan Potensi Jamur Makro di Kawasan Suaka Margasatwa Bukit Rimbang Bukit Baling (SMBRBB) Propinsi Riau, Sumatera

\begin{tabular}{|c|c|c|c|c|}
\hline No & Jenis & Suku & Filum & potensi \\
\hline 120 & Sarcomyxa sp. & Marasmiaceae & Basidiomycota & - \\
\hline 112 & Schizophyllum commune & Mycenaceae & Basidiomycota & Pangan \\
\hline 113 & $\begin{array}{c}\text { Schizophyllum } \\
\text { sp1. }\end{array}$ & $\begin{array}{c}\text { Schizophyll } \\
\text { aceae }\end{array}$ & $\begin{array}{c}\text { Basidiomy } \\
\text { cota }\end{array}$ & $\begin{array}{c}\text { Pangan } \\
\text { /Obat }\end{array}$ \\
\hline 114 & Skleroderma citrinum & Schizophyllaceae & Basidiomycota & Pangan /Obat \\
\hline 115 & Spongiforma sp. & Sklerodermataceae & Basidiomycota & Pangan / Obat \\
\hline 116 & Stereum sp1. & Boletaceae & Basidiomycota & - \\
\hline 117 & Stereum sp2. & Stereaceae & Basidiomycota & Obat \\
\hline 119 & Tricholoma sp & Stereaceae & Basidiomycota & Obat \\
\hline 121 & Thelophora sp. & Tricholomataceae & Basidiomycota & - \\
\hline 123 & Tremella fuciformis & Thelophoraceae & Basidiomycota & Pangan \\
\hline 124 & Trametes versikularis & Tremellaceae & Basidiomycota & Obat \\
\hline 125 & T. versicolor & Polyporaceae & Basidiomycota & Obat \\
\hline 126 & T. repanda & Polyporaceae & Basidiomycota & Obat \\
\hline 127 & T. ochracea & Polyporaceae & Basidiomycota & Obat \\
\hline 128 & Trametes sp1. & Polyporaceae & Basidiomycota & Obat \\
\hline 129 & Trametes sp2. & Polyporaceae & Basidiomycota & Obat \\
\hline 130 & Trametes sp3. & Polyporaceae & Basidiomycota & Obat \\
\hline 131 & Trametes sp4. & Polyporaceae & Basidiomycota & Obat \\
\hline 132 & Trametes sp5 & Polyporaceae & Basidiomycota & Obat \\
\hline 133 & Trichaptum sp. & Polyporaceae & Basidiomycota & Obat \\
\hline 134 & Tyromyces chioneus & Polyporaceae & Basidiomycota & Obat \\
\hline 135 & Volvariella volvacea & Pluteaceae & Basidiomycota & Pangan \\
\hline 136 & Xylaria polymorpha & Xylariaceae & Basidiomycota & Obat \\
\hline 137 & Xylaria longipes & Xylariaceae & Ascomycota & Obat \\
\hline 138 & Xylaria hypoxylon & Xylariaceae & Ascomycota & Obat \\
\hline
\end{tabular}

